PNNL-10988

UC-810

Project Technical Information

RECEIVED

APR O 1996

OSTI

Feed Specification for the Double-

Shell Tank/Single-Shell Tank Waste

Blend for High-Level Waste

Vitrification Process and Melter

Testing

E. M. Tracey

M. D. Merz

G. K. Patello

K. D. Wiemers

February 1996

Prepared for

the U.S. Department of Energy

under Contract DE-AC06-76RLO 1830

Pacific Northwest National Laboratory

Richland, Washington 99352

Battelle 
PNNL-10988

UC-810

Project Technical Information

\section{Feed Specification for the Double-Shell Tank/Single Shell Tank Waste Blend for High-Level Waste Vitrification Process and Melter Testing}
E. M. Tracey
M. D. Merz
G. K. Patello
K. D. Wiemers

February 1996

Prepared for

the U.S. Department of Energy

under Contract DE-AC06-76RLO 1830

Pacific Northwest National Laboratory

Richland, Washington 99352 


\title{
DISCLAIMER
}

This report was prepared as an account of work sponsored by an agency of the United States Government. Neither the United States Government nor any agency thereof, nor Battelle Memorial Institute, nor any of their employees, makes any warranty, express or implied, or assumes any legal liability or responsibility for the accuracy, completeness, or usefulness of any information, apparatus, product, or process disclosed, or represents that its use would not infringe privately owned rights. Reference herein to any specific commercial product, process, or service by trade name, trademark, manufacturer, or othenwise does not necessarily constitute or imply its endorsement, recommendation, or favoring by the United States Government or any agency thereof, or Battelle Memorial institute. The views and opinions of authors expressed herein do not necessarily state or reflect those of the United States Government or any agency thereof.

\section{PACIFIC NORTHWEST NATIONAL LABORATORY operated by BATTELLE for the \\ UNITED STATES DEPARTMENT OF ENERGY under Contract DE-AC06-76RLO 1830}

\author{
Printed in the United States of America \\ Available to DOE and DOE contractors from the \\ Office of Scientific and Technical Information, P.O. 80x 62, Oak Ridge, TN 37831; \\ prices available from (615) 576-8401. \\ Available to the public from the National Technical Information Service, \\ U.S. Department of Commerce, 5285 Port Royal Rd., Springfield, VA 22161
}

\$ 
T3C-95-148

Page 1 of 19

\subsection{INTRODUCTION}

The High-Level Waste (HLW) Vitrification Program is developing technology for the Department of Energy to immobilize high-level and transuranic waste as glass for permanent disposal. In support of the program, Pacific Northwest Laboratory (PNL) is conducting laboratory-scale melter feed preparation studies and HLW melter testing which require a simulated HLW feed. The simulant HLW feed represents a blend of the waste from 177 single shell and double shell tanks. The waste blend composition (Table 1) is based on normalized track radionuclide components (TRAC), historical tank data, and assumptions on the pretreatment of the waste. ${ }^{(1)}$ The HLW simulant feed specification for the waste blend composition provides direction for the preparation of laboratory-scale and largescale HLW blend simulant to be used in melter feed preparation studies and melter testing.

Previous HLW simulants have been prepared with a neutralized current acid waste (NCAW) composition excluding acutely toxic and radioactive elements. The feed specification for the waste blend simulant uses a procedure similar to the preparation procedure for NCAW simulant. The elements $\mathrm{Bi}, \mathrm{W}, \mathrm{Co}, \mathrm{Np}, \mathrm{Re}, \mathrm{Th}, \mathrm{Tl}, \mathrm{Hg}, \mathrm{V}$, and $\mathrm{Cm}$, and the anion, $\mathrm{CN}$, which are present in the blend waste composition are not present in the NCAW simulant composition. Acutely toxic and radioactive species are either substituted or eliminated from the composition (Table 1). The waste blend preparation differs from the NCAW simulant preparation in the addition of mineral phases (boehmite, cancranite, sodium silicate, and silica) as the sources for $\mathrm{Al}$ and $\mathrm{Si}^{\left({ }^{(b)}\right.} \mathrm{As}$ a result, the preparation of $\mathrm{Al}(\mathrm{OH})_{3}$ by addition of $\mathrm{NaOH}$ to $\mathrm{Al}\left(\mathrm{NO}_{3}\right)_{3}$ is eliminated. Cyanide $(\mathrm{CN})$ will be added as $\mathrm{Na}_{2} \mathrm{NiFe}(\mathrm{CN})_{6}$ which has been reported to be the major source of $\mathrm{CN}$ in the tanks (Burger et al. 1991). The addition of $\mathrm{Na}_{2} \mathrm{NiFe}(\mathrm{CN})_{6}$ to the batch is necessary because of possible catalytic reactions and release of toxic gases involving $\mathrm{CN}$. However, there is a possibility of an uncontrollable exothermic reaction with a critical temperature of $330^{\circ} \mathrm{C}$ and a $-3012 \mathrm{~kJ}$ per mole energy release for reaction with $\mathrm{NaNO}_{3}$, and a $-3708 \mathrm{~kJ}$ per mole energy release for reaction with $\mathrm{NaNO}_{2}$ (Burger et al. 1991). Therefore, the decision to add $\mathrm{Na}_{2} \mathrm{NiFe}(\mathrm{CN})_{6}$ in a particular application needs to be carefully considered. As with the NCAW, the organic component of the waste blend simulant will be added as oxalate. This decision was based on the prediction that organic complexants in the waste tanks break down into oxalate (Agnew 1994, p. 50).

The waste blend feed specification is written for the preparation of $1000 \mathrm{~L}$ of waste simulant and is summarized as follows. A stock simulant is prepared by first coprecipitating a hydroxide slurry containing major waste oxide elements ( $\mathrm{Fe}, \mathrm{Ni}, \mathrm{Nd}, \mathrm{Zr}$, and $\mathrm{Mn}$ ). The soluble/slightly soluble salts (halides, hydroxides, nitrates, nitrites, sulfates, borates, phosphates, oxides, and oxalate) are added dry to the major oxide slurry. Four other slurries are added to the major oxides and soluble/slightly soluble slurry: 1. minor components as an insoluble compound slurry (oxides, fluorides), 2.

(a) R.W. Powell. May 1995. "Double-Shell Tank/Single-Shell Tank Waste Blend Composition for High-Level Waste Vitrification Process Testing," Letter to J.M. Creer. \#9452712.

(b) Bunker, B.C., and N.G. Colton, Personal Communication. 
Table 1. HIW Blend Refereace and Simulant Composition

Reference Composition $(\omega)$

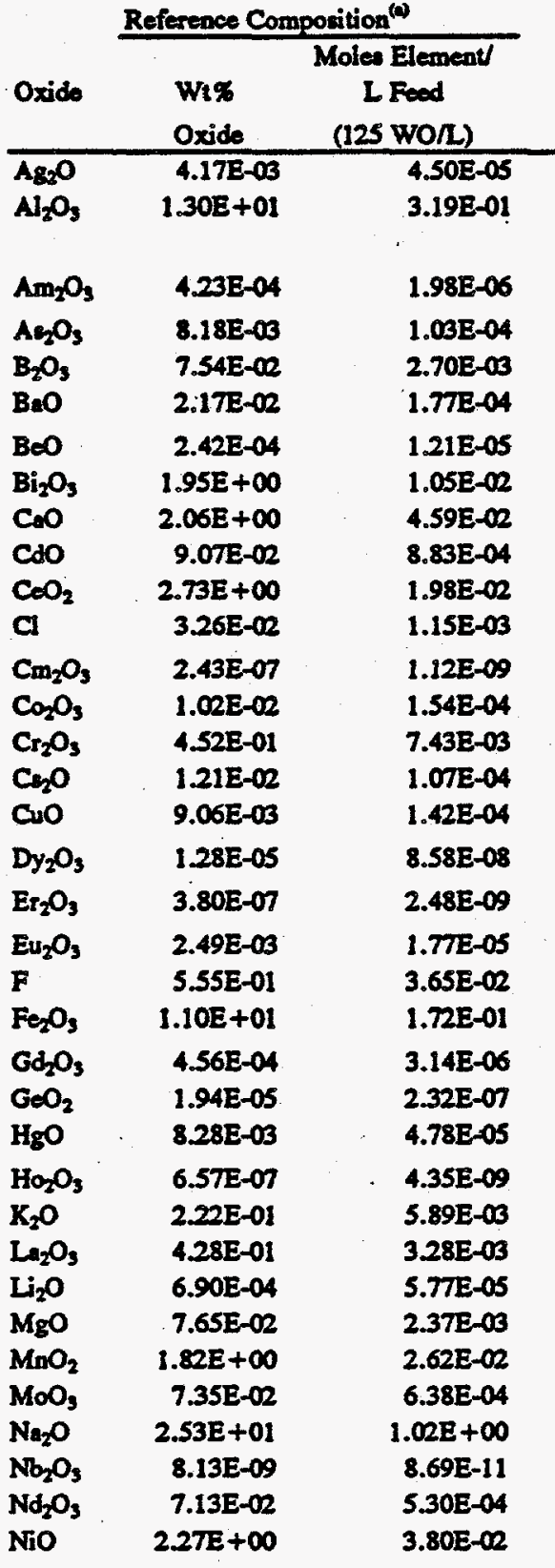

Simulent Componition

\begin{tabular}{|c|c|c|c|}
\hline \multirow[b]{2}{*}{$\begin{array}{l}\text { Subst' } \\
\text { Der(s) }\end{array}$} & \multicolumn{3}{|c|}{ Simulent Composition } \\
\hline & $\begin{array}{c}\text { Moles Element/ } \\
\text { L Feed } \\
\text { (125 \& worL) }\end{array}$ & $\begin{array}{l}\text { Wt\& } \\
\text { Oxide }\end{array}$ & Source Chemical \\
\hline & $\begin{array}{l}4.78 \mathrm{E}-05 \\
3.39 \mathrm{E}-01\end{array}$ & $\begin{array}{r}4.43 \mathrm{E}-03 \\
1.38 \mathrm{E}+01\end{array}$ & $\begin{array}{l}\mathrm{AgNO}_{3} \\
\mathrm{NeAl}_{6} \mathrm{Si}_{6} \mathrm{O}_{24}\left(\mathrm{NO}_{3}\right)_{2} \\
\mathrm{Al}(\mathrm{OOH})\end{array}$ \\
\hline
\end{tabular}

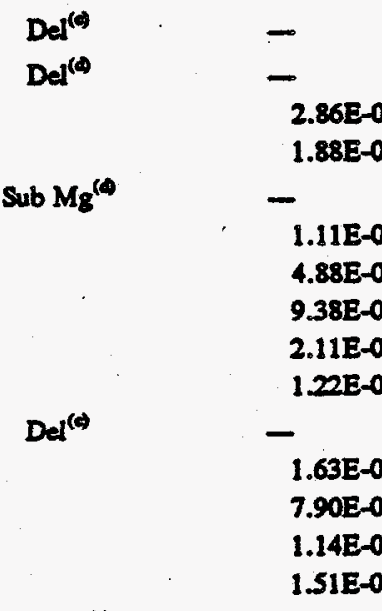

$\longrightarrow$

deleted

8.01E-02 $\mathrm{H}_{3} \mathrm{BO}$, 2.30E-02 $\mathrm{Ba}(\mathrm{OH})_{2} \times 8 \mathrm{H}_{2} \mathrm{O}$

- mubt. MgO

2.07E $+\infty \quad \mathrm{Bi}\left(\mathrm{NO}_{3}\right)_{3} \times 5 \mathrm{H}_{2} \mathrm{O}$

$2.19 \mathrm{E}+\infty \quad \mathrm{Ca}\left(\mathrm{NO}_{3}\right)_{2} \times 4 \mathrm{H}_{2} \mathrm{O}$

9.63E-02 $\mathrm{Cd}\left(\mathrm{NO}_{3}\right)_{2} \times 4 \mathrm{H}_{2} \mathrm{O}$

$2.90 \mathrm{E}+\infty \mathrm{Ce}\left(\mathrm{NO}_{3}\right)_{3} \times 6 \mathrm{H}_{2} \mathrm{O}$

3.46E-02 $\mathrm{N}=\mathrm{Cl}$

- delete

$1.08 \mathrm{E}-\mathrm{O2} \quad \mathrm{Co}\left(\mathrm{NO}_{3}\right)_{2} \times 6 \mathrm{H}_{2} \mathrm{O}$

4.80E-01 $\mathrm{Cr}\left(\mathrm{NO}_{3}\right)_{3} \times \mathrm{OH}_{2} \mathrm{O}$

$1.29 \mathrm{E}-02 \quad \mathrm{CaNO}_{3}$

9.62E-03 $\mathrm{CuSO}_{4} \times \mathrm{SH}_{2} \mathrm{O}$

Sub $\mathrm{Nd}^{(0)} \quad$ - $\quad-\quad$ aubst. $\mathrm{Nd}_{2} \mathrm{O}_{3}$

Sub $\mathrm{Nd}^{(0)} \quad$ - $\quad$ - $\quad$ subst. $\mathrm{Nd}_{2} \mathrm{O}_{3}$

Sub Nd(o)

$-$

3.88E-02

$1.83 \mathrm{E}-01$

Sub Nd(s)

-

2.46E-07

$5.08 \mathrm{E}-05$

Sub Nd(s)

6.26E-03

3.49E-03

6.13E-05

2.53E-03

2.78E-0R

$6.78 E-04$

$1.08 E+\infty$

9.23E-11

$6.83 E-02$

4.04E-02
$-$

5.89E-01

1.17E +01

-

2.06E-05

8.79E-03

-

2.36E-01

4.55E-01

7.33E-04

8.17E-02

$1.93 E+\infty$

7.81E-02

$2.69 \mathrm{E}+01$

8.64E- 09

$9.19 \mathrm{E}+\infty 0$

$2.41 E+\infty$ wbst. $\mathrm{Nd}_{2} \mathrm{O}_{3}$ $\mathrm{Fe}\left(\mathrm{NO}_{3}\right)_{3} \mathrm{OH}_{2} \mathrm{O}$ wubrt. $\mathrm{Nd}_{2} \mathrm{O}_{3}$ $\mathrm{GeO}_{2}$ $\mathrm{HgO}$

aubet. $\mathrm{Nd}_{2} \mathrm{O}_{3}$ KOH $\left.\mathrm{La}_{(\mathrm{OH}}\right)_{3}$ and $\mathrm{LaF}_{3}$ $\mathrm{Li}_{2} \mathrm{O}$ $\mathrm{Mg}\left(\mathrm{NO}_{3}\right)_{2} \times 6 \mathrm{H}_{2} \mathrm{O}$ $\mathrm{Mn}\left(\mathrm{NO}_{3}\right)_{2}$ and $\mathrm{KMnO}_{4}$ $\mathrm{MoO}_{3}$ $\mathrm{NaOH}$ $\mathrm{Nb}_{2} \mathrm{O}_{5}$ $\mathrm{Nd}\left(\mathrm{NO}_{3}\right)_{3} \times 6 \mathrm{H}_{2} \mathrm{O}$ and $\mathrm{NdF}_{3}$ $\mathrm{Ni}\left(\mathrm{NO}_{3}\right)_{2} \times 6 \mathrm{H}_{2} \mathrm{O}$ $\mathrm{NaF}\left(\sec \mathrm{LAF}_{3} \& \mathrm{NdF}_{3}\right)$ 


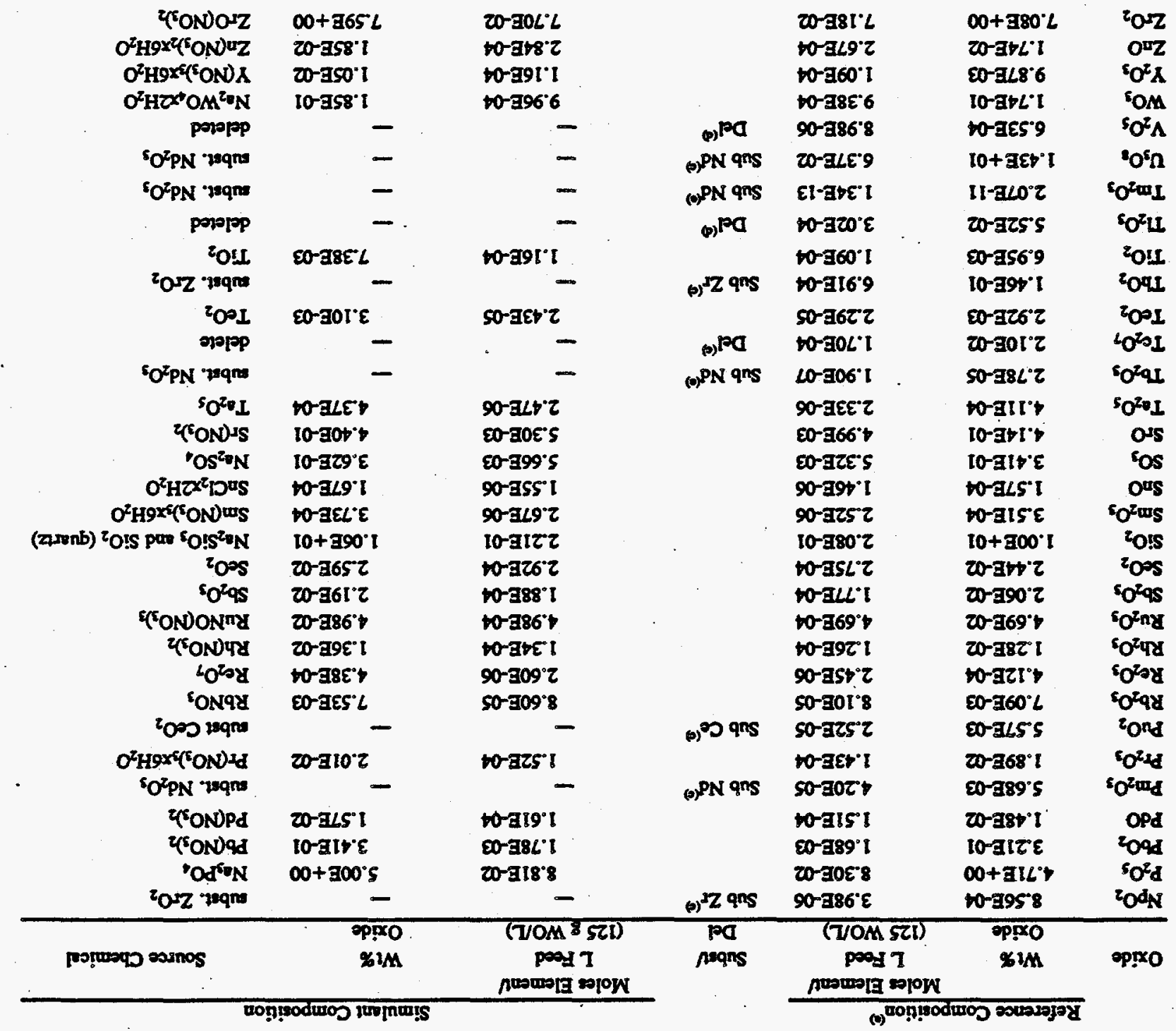

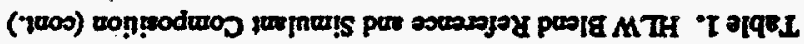


Table 1. HIW Blead Reference and Simulant Composition (cont.)

Volatiles Components of the HLW Blend

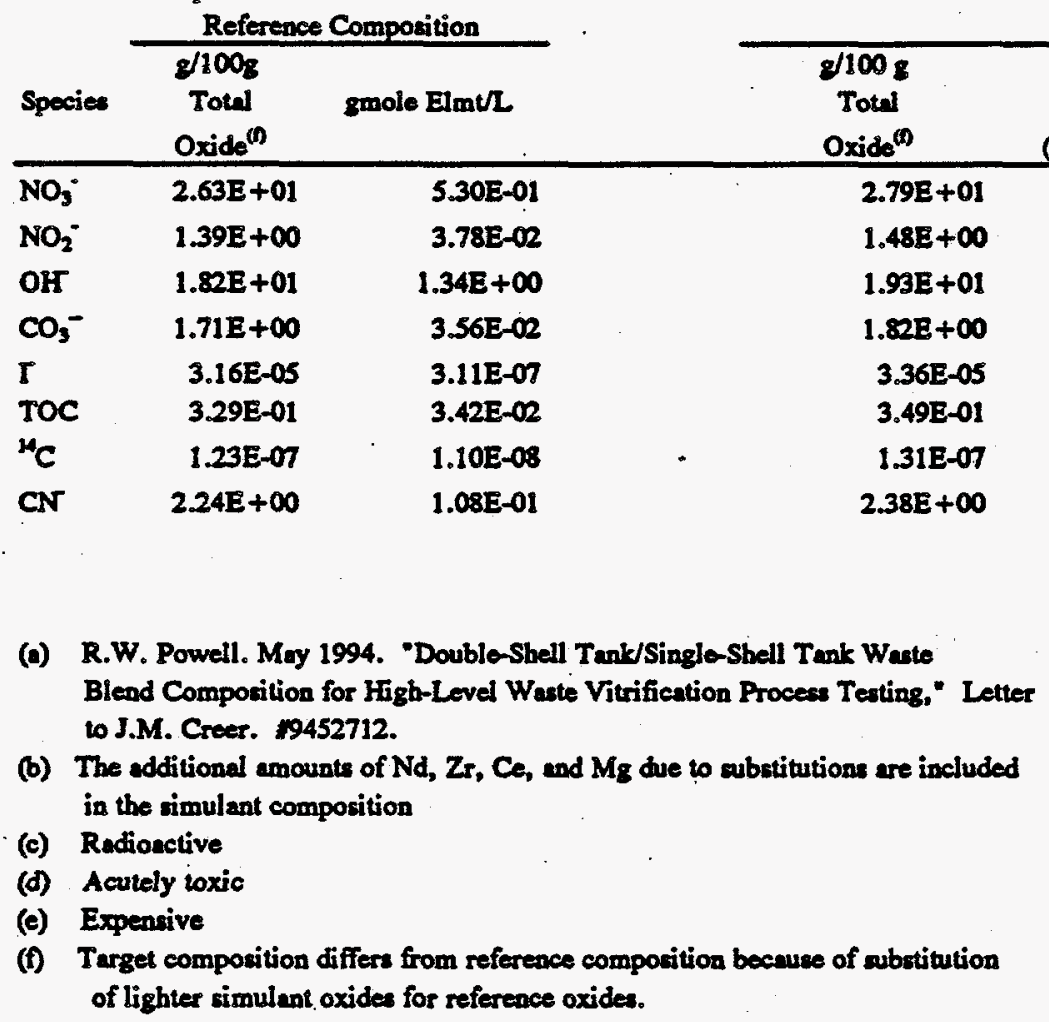

Simulent Composition

- Anioarl Source

(125 g oxide/L)

Chemical

$\begin{array}{rl}3.29 \mathrm{E}+01 & \mathrm{NaNO}_{3} \\ 1.74 \mathrm{E}+\infty & \mathrm{NaNO}_{2} \\ 2.28 \mathrm{E}+01 & \mathrm{NaOH} \\ 2.14 \mathrm{O}+\infty & \mathrm{Na}_{2} \mathrm{CO}_{3} \\ 3.95 \mathrm{E}-05 & \mathrm{NaIO}_{3} \\ 4.11 \mathrm{E}-01 & \mathrm{Na}_{2} \mathrm{C}_{2} \mathrm{O}_{4} \\ - & \text { delete } \\ 2.80 \mathrm{E}+\infty & \mathrm{Na}_{2} \mathrm{NiFe}(\mathrm{CN})_{6}\end{array}$


coprecipitated noble metals ( $R h, P d, R u$ ) slurry, 3. sodium nickel ferrocyanide slurry, and 4. a mineral slurry. Excess nitrate and sodium are removed by washing. The washed feed is analyzed for sodium, nitrite, and nitrate. These anions and cations have been added in various amounts with other elements and appropriate additions are made to bring these components to nominal levels. Figure 1 is a flowchart of the simulant preparation steps.

The waste blend feed specification represents a best effort to reproduce the speciation and particle size of the components in the waste tanks based on historical reports and process knowledge and within the programmatic funding and schedule constraints. An actual blend of the Hanford tanks combines wastes resulting from multiple process streams. The blend simulant preparation does not mimic each of these process streams, only the final composition of a blended waste. The feed specification includes many minor components except those which are acutely toxic. The deletion of these elements was carefully considered with regards to properties which may influence catalytic behavior or the glass properties. Additional deletions may be considered for melter evaluation testing depending on batch size, expense of minor components (i.e. noble metals), and safety issues, and should be carefully evaluated. Radioactive elements are deleted or substituted. Neodymium is the surrogate element for $U$. In the waste blend, component $U$ is a major component ( $14 \mathrm{wt} \%)$. When previously substituted for in the NCAW, U was a minor component ( $-5 \mathrm{wt} \%)$. This represents a limitation in the specification because Nd does not exactly mimic the properties of $U$, and its molecular weight is significantly less than the molecular weight of U. As a result, a HLW waste blend with a gram waste oxide loading of $125 \mathrm{~g}$ waste oxide/ liter (gWO/L) is equivalent to a waste blend simulant with a gram waste oxide loading of $117.8 \mathrm{gWO} / \mathrm{L}$. These limitations need to be considered with respect to the application for which the feed specification is used.

A laboratory-scale preparation of the HLW blend simulant per the steps outlined in this specification is scheduled to be completed by February 1995. A revision to the specification will be issued to address any necessary changes. 


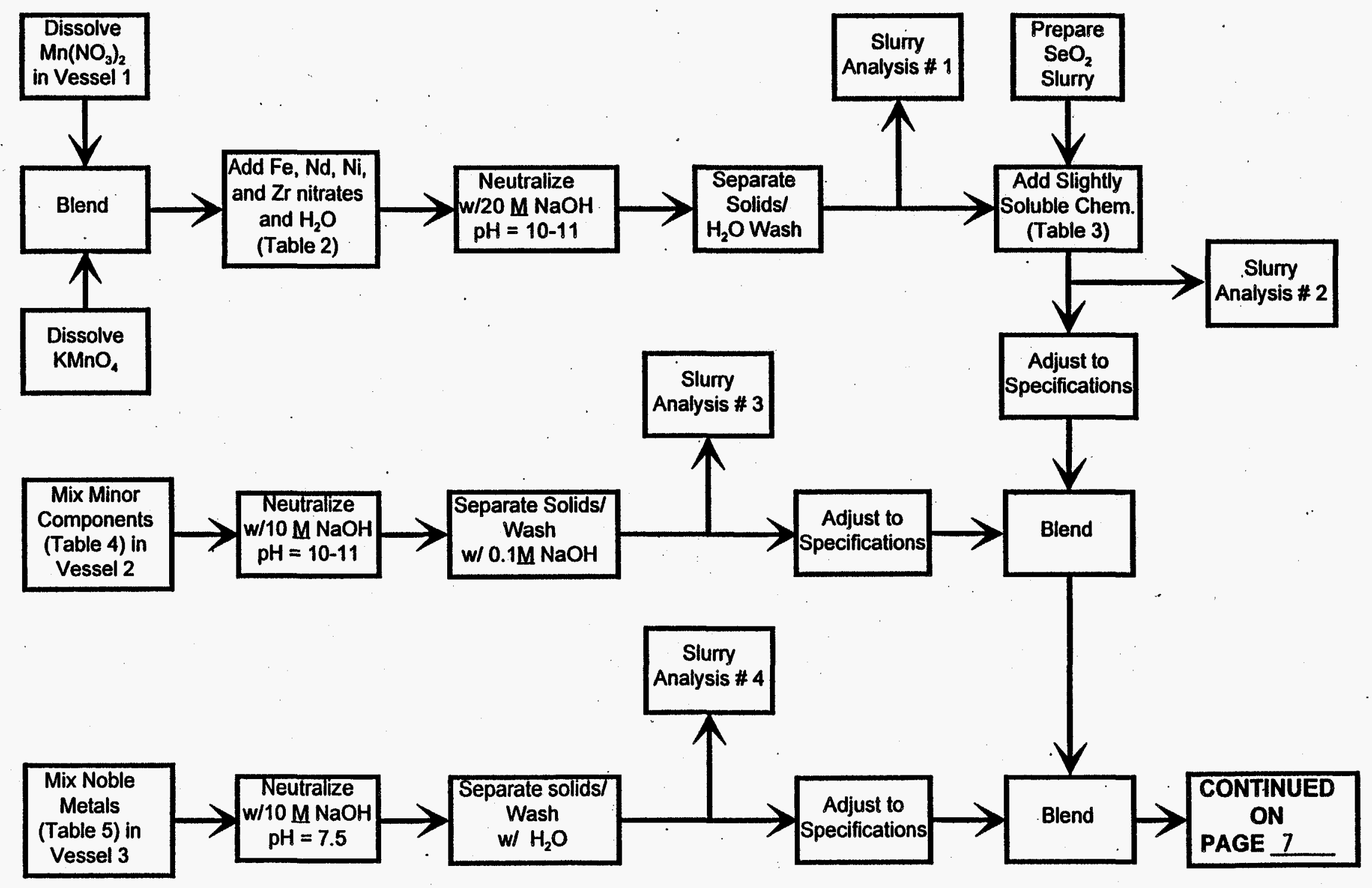

Figure 1. HLW Blend Simulant Preparation Flowsheet 


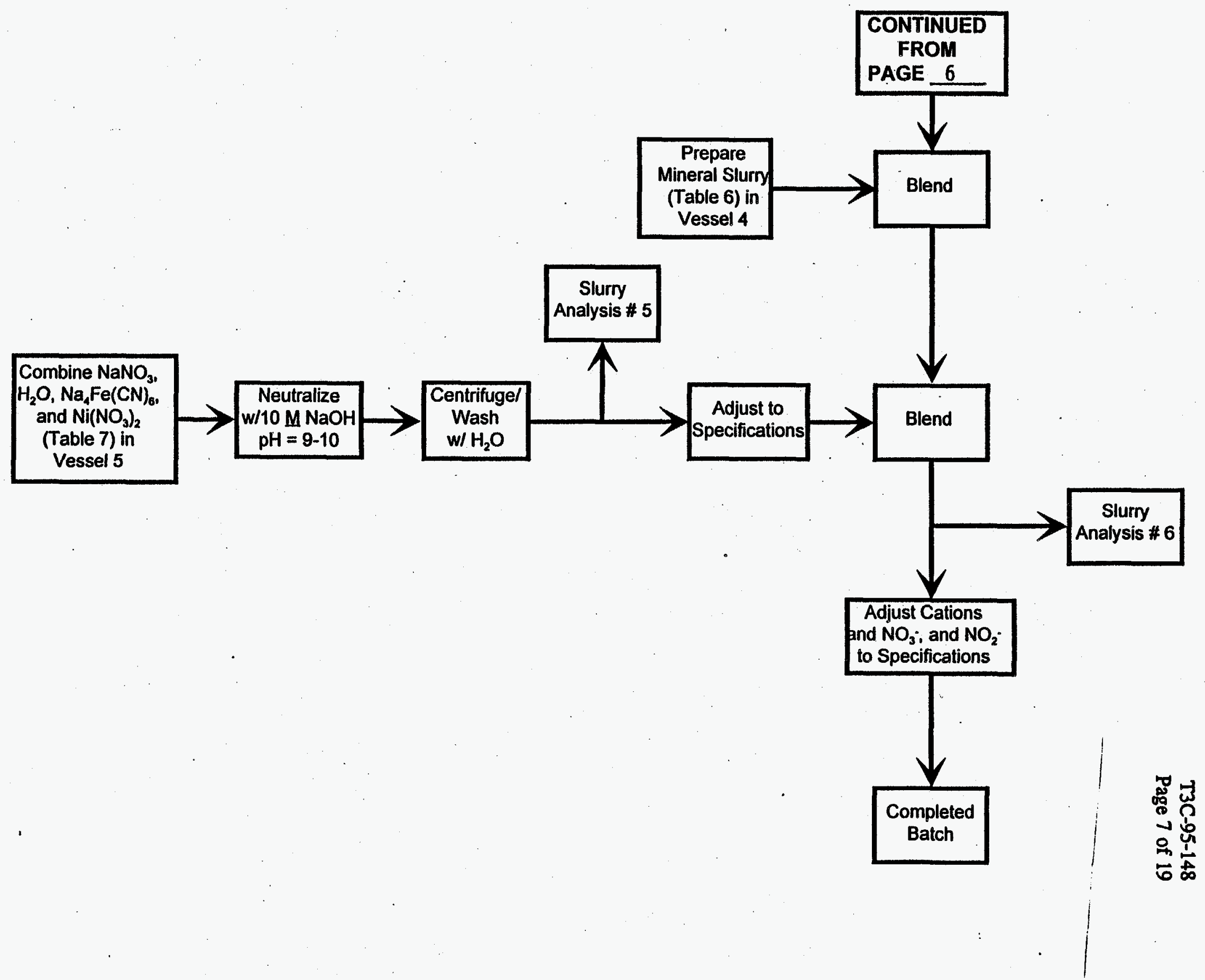


T3C-95-148

Page 8 of 19

\subsection{HLW BLEND SIMULANT PREPARATION PROCEDURE}

Chemicals added as solids are to be in the form of fine powders to ensure that complete dispersion and homogeneity will occur: This may require some chemicals to be ground or crushed prior to addition. The use of a grinder pump or other shearing device to assure solids are broken down is acceptable. Highly toxic and carcinogenic materials are indicated in the tables by shading. These materials should be handled in ventilated areas with appropriate personnel protection.

The vessels used in this procedure should be equipped with a cooling capabilities, an agitating impeller, and tank ventilation. During the preparation, slurry temperatures should be maintained below $40^{\circ} \mathrm{C}$ to control exothermic reactions during the hydroxide precipitation steps. Agitation times should be sufficient to ensure complete dispersion and homogeneity of the slurries. Determination of the appropriate agitation times is left up to the user.

The capacity of the tanks used will determine the number of washing steps required to remove excess sodium nitrate. Analysis steps are to only be used as verification that all the chemicals were added and added in the correct amounts. Uncertainties in the analytical data should be considered before the use of these measurements for chemical adjustments.

A centrifuge should be used for all the solids separation steps. Primary constraints in the selection of solids separation methods include retention of solids to meet total quantity requirements and prevention of conditions that will alter physical properties and/or chemical species of components. Results of previous work at PNL have shown that the chemical species of iron and zirconium can be affected on exposure to air. For this reason, separation methods should be chosen to limit the solids concentration of the slurries to a maximum of $30 \mathrm{wt} \%$ during intermediate processing steps. Using a settle/decant separation method is not recommended due to the potential formation of a suspension that gels and requires large quantities of dilution water and extended settling times.

Quantities of the components used to prepare the simulant are identified in the following procedure by $[X]$, where $X$ is $A, B, C$, etc. Values of $A, B, C$, etc. can be found in the tables. Highly toxic or carcinogenic components are shaded and no radioactive constituents are added.

\subsection{Preparation of Major Component Slurry}

This part of the procedure provides instructions to precipitate $\mathrm{MnO}_{2}$ and neutralize, precipitate, and wash a major component hydroxide slurry. Quantities of the components can be found in Table 2.

A. Charge vessel 1 with [A] $L$ of water.

B. Add [B] g of manganese nitrate $\left\{\mathrm{Mn}\left(\mathrm{NO}_{3}\right)_{2}\right\}$ solution while continuously stirring. Maintaining the temperature between $35^{\circ} \mathrm{C}$ and $40^{\circ} \mathrm{C}$ will hasten $\mathrm{Mn}\left(\mathrm{NO}_{3}\right)_{2}$ dissolution. 
T3C-95-148

Page 9 of 19

Table 2: Major Components(

\begin{tabular}{|c|c|c|c|}
\hline Item & Component & Unit & Quantity \\
\hline [A] & Dilution Water & L & 100 \\
\hline [B] & $\mathrm{Mn}\left(\mathrm{NO}_{3}\right)_{2}$ & g & $3.62 \times 10^{3}$ \\
\hline [C] & $\mathrm{KMnO}_{4}$ & g & $9.31 \times 10^{2}$ \\
\hline [D] & Dilution Water & L & 100 \\
\hline [E] & Dilution Water & $\mathbf{L}$ & 300 \\
\hline [F] & $\mathrm{Fe}\left(\mathrm{NO}_{3}\right)_{3} \cdot 9 \mathrm{H}_{2} \mathrm{O}^{(b)}$ & $\mathbf{g}$ & $6.23 \times 10^{4}$ \\
\hline [G] & $\mathrm{ZrO}\left(\mathrm{NO}_{3}\right)_{2}$ & g & $1.68 \times 10^{4}$ \\
\hline [15] & $\mathrm{Ni}\left(\mathrm{NO}_{3}\right)_{2} 6 \mathrm{H}_{2} \mathrm{O}^{2}$ & 8. & $5.83 \times 10^{3}$ \\
\hline [I] & $\mathrm{Nd}\left(\mathrm{NO}_{3}\right)_{3} \cdot 6 \mathrm{H}_{2} \mathrm{O}$ & $\mathbf{g}$ & $2.79 \times 10^{4}$ \\
\hline [J] & $20 \mathrm{M} \mathrm{NaOH}$ & L & 100 \\
\hline$[\mathrm{K}]$ & Wash Water & L & 700 \\
\hline
\end{tabular}

C. In a separate vessel, blend [C] $\mathrm{g}$ of potassium permanganate $\left\{\mathrm{KMnO}_{4}\right\}$ with [D] $\mathrm{L}$ of water under constant agitation. Adjust the temperature to $35^{\circ} \mathrm{C}$ to $40^{\circ} \mathrm{C}$ to assure the permanganate will fully dissolve.

D. Pump the permanganate solution (prepared in step C) into vessel 1 containing the $\mathrm{Mn}\left(\mathrm{NO}_{3}\right)_{2}$ (prepared in step $\mathrm{B}$ ) at a rate such that the temperature of the slurry does not increase above $40^{\circ} \mathrm{C}$. During this step, insoluble $\mathrm{MnO}_{2}$ will form.

(a) Highly toxic or carcinogenic components are shaded.

(b) If sodium nickel ferrocyanide is omitted or if the amount is decreased from the value given in section 2.6, the amount of iron should be increased to account for the iron that would have been added with the sodium nickel ferrocyanide.

(c) If sodium nickel ferrocyanide is omitted or if the amount is decreased from the value given in section 2.6, the amount of nickel should be increased to account for the nickel that would have been added with the sodium nickel ferrocyanide. 
E. With continued agitation, add $[E] \mathrm{L}$ of water, $[\mathrm{F}] \mathrm{g}$ of ferric nitrate nonahydrate $\left\{\mathrm{Fe}\left(\mathrm{NO}_{3}\right)_{3} \cdot 9 \mathrm{H}_{2} \mathrm{O}\right\},[\mathrm{G}] \mathrm{g}$ of zirconium nitrate pentahydrate $\left\{\mathrm{Zr}\left(\mathrm{NO}_{3}\right)_{4} \cdot 5 \mathrm{H}_{2} \mathrm{O}\right\},[\mathrm{H}] \mathrm{g}$ of nickel nitrate hexahydrate $\left\{\mathrm{Ni}\left(\mathrm{NO}_{3}\right)_{2} \cdot 6 \mathrm{H}_{2} \mathrm{O}\right\}$, and $\mathrm{m} \mathrm{g}$ of neodymium nitrate hexahydrate $\left\{\mathrm{Nd}\left(\mathrm{NO}_{3}\right)_{2}, 6 \mathrm{H}_{2} \mathrm{O}\right\}$ to vessel 1 .

F. Agitate until the nitrates are completely dissolved. Please note that precipitated $\mathrm{MnO}_{2}$ will not dissolve during this step.

G. In a separate vessel, prepare a $20 \mathrm{M} \mathrm{NaOH}$ solution of approximate volume [J] $\mathrm{L}$.

H. Stirring constantly, add approximately [J] $\mathrm{L}$ of $20 \mathrm{M} \mathrm{NaOH}$ solution slowly to the solution in vessel 1 until the $\mathrm{pH}$ is in the range of 10 to 11 and stable (a variation of not more than \pm 0.2 $\mathrm{pH}$ units over 10 minutes). Control $\mathrm{NaOH}$ addition rate and provide cooling if necessary during $\mathrm{NaOH}$ addition to maintain the temperature of the slurry below $40^{\circ} \mathrm{C}$.

I. After a pH between 10 and 11 is reached, continue to agitate the slurry for 1 hour. If the $\mathrm{pH}$ has dropped below 10 after the $1 \mathrm{hr}$ mixing period, add additional $\mathrm{NaOH}$ to return the $\mathrm{pH}$ to between 10 and 11 .

J. Perform water wash/solids separation sequence (using a centrifuge and leaving a final volume such that the weight percent solids of the slurry is less than $20 \mathrm{wt} \%$ ) to lower the total amount of soluble nitrate to less than $15 \mathrm{~g}$ for every liter of final total volume (i.e. $1000 \mathrm{~L}$ ). It is estimated, based on past preparations, that 2 to 3 equivalent volumes, a total of $[\mathrm{K}] \mathrm{L}$ of water, will be needed to reduce the amount of nitrate below the maximum allowable limit. SOLIDS CONCENTRATION MUST BE MAINTAINED BELOW 30 wt\% DURING SEPARATION PROCESS so $\mathrm{Zr}$ and $\mathrm{Fe}$ species are not exposed to air.

K. Agitate the contents in vessel 1 and collect a representative sample for analysis. Analyze the sample (slurry analysis 1) and determine the amount of nitrate and cations retained in the slurry to confirm sufficient washing has occurred to decrease the nitrate and that major cationic species have not been lost (except for sodium). Major cations, excluding Na, should be within $\pm 10 \%$ of target values listed in Table 2 . The amount of nitrate retained should be less than $15 \mathrm{~g}$ for every liter of the final total volume (i.e. $1000 \mathrm{~L}$ ).

\subsection{Addition of Soluble and Slightly Soluble Components}

This part of the procedure provides instructions to add the soluble and slightly soluble components to the major hydroxide slurry. Quantities of the components can be found in Table 3.

A. While continuously agitating vessel 1 , add the soluble and slightly soluble components to the vessel in the order and amounts shown in Table 3. The carcinogenic and highly toxic components should be pre-slurried in a ventilation hood using water with the appropriate respiratory precautions and poured into vessel 1.

B. Agitate the vessel contents and collect a representative sample for analysis. Analyze the sample (slurry analysis 2) to confirm the amount of components in the slurry. Major cations should be within $\pm 10 \%$ of target values listed in Table 2 and the soluble/slightly soluble components should be within $\pm 15 \%$ of the values specified in Table 3. 
T3C-95-148

Page 11 of 19

Table 3: Soluble and Slightly Soluble Components ${ }^{(4)}$

\begin{tabular}{|c|c|c|c|}
\hline liem & Component & Unit & Quantity \\
\hline [A] & $\mathrm{NaCl}$ & $\mathbf{g}$ & $6.70 \times 10^{1}$ \\
\hline [B] & $\mathrm{Na}_{2} \mathrm{WO}_{4} \cdot 2 \mathrm{H}_{2} \mathrm{O}$ & g & $3.09 \times 10^{2}$ \\
\hline [C] & $\mathrm{NaIO}_{3}$ & $\mathbf{g}$ & $6.20 \times 10^{-2}$ \\
\hline [D] & $\mathrm{SnCl}_{2} \cdot 2 \mathrm{H}_{2} \mathrm{O}$ & g & $3.29 \times 10^{-1}$ \\
\hline [E] & $\mathrm{KOH}$ & $\mathbf{g}$ & $3.31 \times 10^{2}$ \\
\hline [F] & $\mathrm{Na}_{2} \mathrm{SO}_{4}$ & $\mathbf{g}$ & $7.36 \times 10^{2}$ \\
\hline [G] & $\mathrm{CuSO}_{4} \cdot 5 \mathrm{H}_{2} \mathrm{O}$ & g & $3.56 \times 10^{1}$ \\
\hline [H] & $\mathrm{H}_{3} \mathrm{BO}_{3}$ & $\mathbf{g}$ & $1.67 \times 10^{2}$ \\
\hline$[1]$ & $\mathrm{Na}_{3} \mathrm{PO}_{4}$ & $\mathbf{g}$ & $1.36 \times 10^{4}$ \\
\hline [J] & $\mathrm{Na}_{2} \mathrm{CO}_{3}$ & $\mathbf{g}$ & $3.78 \times 10^{3}$ \\
\hline [K] & $\mathrm{Na}_{2} \mathrm{C}_{2} \mathrm{O}_{4}$ & g & $4.59 \times 10^{3}$ \\
\hline 16 & $\mathrm{Ba}(\mathrm{OH}), 8 \mathrm{H}_{2} \mathrm{O}$ & 8. & $558 \times 10^{1}$ \\
\hline [M] & $\mathrm{MoO}_{3}$ & g & $9.19 \times 10^{1}$ \\
\hline (N) & $\mathrm{Sb}_{2} \mathrm{O}_{3}$ & 8. & $2.58 \times 10$ \\
\hline [O] & $\mathrm{Re}_{2} \mathrm{O}_{7}$ & $\mathbf{g}$ & $5.95 \times 10^{-1}$ \\
\hline [P] & $\mathrm{CsNO}_{3}$ & g & $2.09 \times 10^{1}$ \\
\hline [Q] & $\mathrm{Sr}\left(\mathrm{NO}_{3}\right)_{2}$ & $\mathbf{g}$ & $1.06 \times 10^{3}$ \\
\hline Ris. & $\mathrm{SeO}_{2}$ & 8 & $3^{3} .05 \times 10^{\prime}=$ \\
\hline
\end{tabular}

(a)

Highly toxic or carcinogenic components are shaded. 
T3C-95-148

Page 12 of 19

\subsection{Preparation and Addition of Minor and Insoluble Components Slurry}

This part of the procedure provides instructions to neutralize, precipitate, and wash a mixture of minor components and insoluble chemicals. Quantities of the components can be found in Table 4.

A. To a second vessel (vessel 2) add approximately [A] L of water. Add components [B] through [Y] given in Table 4 in the order and amount shown. Any insoluble components should be ground to a maximum diameter of $0.1 \mathrm{~mm}$ prior to being introduced to the tanks.

B. In a separate vessel, prepare $10 \mathrm{M} \mathrm{NaOH}$ solution of approximate volume [Z] $\mathrm{L}$.

C. Stirring constantly, add approximately [Z] L of $10 \mathrm{M} \mathrm{NaOH}$ solution slowly to the solution in vessel 2 until the $\mathrm{pH}$ is in the range of 10 to 11 and stable (a variation of not more than \pm 0.2 $\mathrm{pH}$ units over 10 minutes). Control $\mathrm{NaOH}$ addition rate and provide cooling if necessary during $\mathrm{NaOH}$ addition to maintain the temperature of the slurry below $40^{\circ} \mathrm{C}$.

D. After a pH between 10 and 11 is reached, continue to agitate the slurry for 1 hour. If the $\mathrm{pH}$ has dropped below 10 after the $1 \mathrm{hr}$ mixing period, add additional $\mathrm{NaOH}$ to return the $\mathrm{pH}$ to between 10 and 11 .

E. In a separate vessel, prepare a $0.1 \mathrm{M} \mathrm{NaOH}$ solution of approximate volume [AA] L.

F. Perform the wash/solids separation sequence (using a centrifuge and leaving a final volume such that the weight percent solids of the slurry is less than $20 \mathrm{wt} \%$ ) to lower the amount of soluble nitrate less than $5 \mathrm{~g}$ for every liter of final total volume (i.e. $1000 \mathrm{~L}$ ). The wash solution is to be a $0.1 \mathrm{M} \mathrm{NaOH}$ solution which will preserve the high $\mathrm{pH}$ of the solution. It is estimated based on past preparations, that 2 to 3 equivalent volumes, a total of $[\mathrm{AA}] \mathrm{L}$, of the $\mathrm{NaOH}$ solution will be needed to reduce the $\mathrm{NO}_{3}{ }^{-}$concentration below the maximum allowable limit.

G. Agitate the vessel contents and collect a representative sample for analysis. Analyze the sample (slurry analysis 3 ) and determine the amount of components retained in the slurry to confirm sufficient washing has occurred and that ionic species (except sodium) bave not been lost. The amount of nitrate retained should be less than $5 \mathrm{~g}$ for every liter of the final total volume (i.e. $1000 \mathrm{~L}$ ). The minor and insoluble components should be within $\pm 15 \%$ of the values specified in Table 4.

H. Transfer the washed slurry to the blend in vessel 1 as shown in Figure 1. 
T3C-95-148

Page 13 of 19

Table 4: Minor Component Nitrates and Insolubles ${ }^{(4)}$

\begin{tabular}{|c|c|c|c|c|c|c|c|}
\hline \multicolumn{4}{|c|}{ Minor Components } & \multicolumn{4}{|c|}{ Insolubles } \\
\hline Item & Compound & Unit & Quantity & Item & Compound & Unit & Quantity \\
\hline [A] & Dilution Water & $\mathbf{L}$ & 355 & [P] & $\mathrm{GeO}_{2}$ & $\mathbf{g}$ & $2.24 \times 10^{-2}$ \\
\hline (B) & $\mathrm{ed}\left(\mathrm{NO}_{3}\right)_{2} \mathrm{HH}_{2} \mathrm{O}$ & 8 & $272 \times 10^{2}$ & [Q] & $\mathrm{HgO}$ & $\mathbf{g}$ & $1.04 \times 10^{1}$ \\
\hline \% & $\left.\mathrm{Cr} \mathrm{NO}_{3}\right)_{3} 9 \mathrm{H}_{2} \mathrm{O}$ & 8 & $298 \times 10^{3}$ & [R] & $\mathrm{LaF}_{3}$ & $\mathbf{g}$ & $6.43 \times 10^{2}$ \\
\hline [D] & $\mathrm{Ce}\left(\mathrm{NO}_{3}\right)_{3} \cdot 6 \mathrm{H}_{2} \mathrm{O}$ & $\mathbf{g}$ & $8.62 \times 10^{3}$ & [S] & $\mathrm{Li}_{2} \mathrm{O}$ & $\mathbf{g}$ & $8.63 \times 10^{-1}$ \\
\hline [E] & $\mathrm{Co}\left(\mathrm{NO}_{3}\right)_{2} \cdot 6 \mathrm{H}_{2} \mathrm{O}$ & g & $4.47 \times 10^{1}$ & {$[\mathrm{~T}]$} & $\mathrm{NaF}$ & $\mathbf{g}$ & $1.04 \times 10^{3}$ \\
\hline [F] & $\mathrm{Ca}\left(\mathrm{NO}_{3}\right)_{2} \cdot 4 \mathrm{H}_{2} \mathrm{O}$ & $\mathbf{g}$ & $1.08 \times 10^{4}$ & [U] & $\mathrm{Nb}_{2} \mathrm{O}_{5}$ & $\mathbf{g}$ & $1.16 \times 10^{-5}$ \\
\hline [G] & $\mathrm{Mg}\left(\mathrm{NO}_{3}\right)_{2} \cdot 6 \mathrm{H}_{2} \mathrm{O}$ & $\mathbf{g}$ & $6.12 \times 10^{2}$ & [V] & $\mathrm{NdF}_{3}$ & $\mathbf{g}$ & $1.19 \times 10^{2}$ \\
\hline [H] & $\mathrm{Bi}\left(\mathrm{NO}_{3}\right)_{3} \cdot 5 \mathrm{H}_{2} \mathrm{O}$ & $\mathbf{g}$ & $5.07 \times 10^{3}$ & [W] & $\mathrm{Ta}_{2} \mathrm{O}_{5}$ & $\mathbf{g}$ & $5.15 \times 10^{-1}$ \\
\hline [I] & $\mathrm{Pr}\left(\mathrm{NO}_{3}\right)_{3} \cdot 6 \mathrm{H}_{2} \mathrm{O}$ & $\mathbf{g}$ & $6.23 \times 10^{1}$ & [X] & $\mathrm{TeO}_{2}$ & g & $3.65 \times 10^{0}$ \\
\hline [J] & $\mathrm{Sm}\left(\mathrm{NO}_{3}\right)_{3} \cdot 6 \mathrm{H}_{2} \mathrm{O}$ & $\mathbf{g}$ & $1.12 \times 10^{0}$ & Mo. & $110_{2}$ & 8 & $8.69 \times 10^{\circ}$ \\
\hline [K] & $\mathrm{Y}\left(\mathrm{NO}_{3}\right)_{3} \cdot 6 \mathrm{H}_{2} \mathrm{O}$ & $\mathbf{g}$ & $4.19 \times 10^{1}$ & {$[Z]$} & $10 \mathrm{M} \mathrm{NaOH}$ & $\mathbf{L}$ & 50 \\
\hline [L] & $\mathrm{Zn}\left(\mathrm{NO}_{3}\right)_{2} \cdot 6 \mathrm{H}_{2} \mathrm{O}$ & $\mathbf{g}$ & $7.95 \times 10^{1}$ & [AA] & $0.1 \mathrm{M} \mathrm{NaOH}$ & $\mathbf{L}$ & 200 \\
\hline (M] & agno & 8 & $1964 \times 10^{\circ}$ & & & & \\
\hline$[\mathrm{N}]$ & $\mathrm{RbNO}_{3}$ & $\mathbf{g}$ & $1.19 \times 10^{1}$ & & & & \\
\hline$[0]$ & $\mathrm{Pb}\left(\mathrm{NO}_{3}\right)_{2}$ & 8. & $556 \times 10^{2}$ & & & & \\
\hline
\end{tabular}

(a) Highly toxic or carcinogenic components are shaded. 
T3C-95-148

Page 14 of 19

\subsection{Preparation and Addition of Noble Metals}

This part of the procedure provides instructions to neutralize, precipitate, and wash a mixture of noble metals $(\mathrm{Ru}, \mathrm{Pd}$, and $\mathrm{Rh})$. Quantities of the components can be found in Table 5.

A. Prepare the noble metal solution in vessel 3 by placing $[\mathrm{A}] \mathrm{g}$ of $\mathrm{Rh}\left(\mathrm{NO}_{3}\right)_{3},[\mathrm{~B}] \mathrm{g}$ of RuNO(NO$)_{3}$, and $[C] \mathrm{g}$ of $\mathrm{Pd}\left(\mathrm{NO}_{3}\right)_{2}$ in [D] L of $4 \mathrm{M} \mathrm{HNO}_{3}$.

B. Add $10 \mathrm{M} \mathrm{NaOH}$, approximately $[E] \mathrm{L}$ to the noble metal slurry until pH reaches $7.5 \pm 0.5$. A brown precipitate will form around a $\mathrm{pH}$ of 6 .

C. Boil slurry for 10 minutes or until the supernate becomes clear.

D. Perform a wash/solids separation sequence (using a centrifuge and leaving a final volume such that the weight percent solids of the slurry is less than $20 \mathrm{wt} \%$ ) to lower the amount of soluble nitrate to less than $5 \mathrm{~g}$ per final total volume (i.e. $1000 \mathrm{~L}$ ). The wash solution is to be deionized water. It is estimated based on past preparations, that 2 to 3 equivalent volumes of water, a total of $[F] \mathrm{L}$, will be needed to reduce the nitrate concentration below the maximum allowable limit.

E. Agitate the vessel contents and collect a representative sample for analysis. Analyze the sample (slurry analysis 4) and determine the amount of nitrate and cations retained in the slurry to confirm sufficient washing has occurred and that cationic species have not been lost. The amount of nitrate retained should be less than $5 \mathrm{~g}$ for every liter of the final total volume (i.e. $1000 \mathrm{~L}$ ). The noble metal components should be within $\pm 15 \%$ of the values specified in Table 5. Document the composition of the product slurry.

F. Transfer the washed slurry to the blend in vessel 1 as shown in Figure 1.

$\therefore$ Table 5: Noble Metals Slurry Components ${ }^{(\omega)}$

\begin{tabular}{|c|c|c|c|}
\hline Item & Component & Unit & Amount \\
\hline [A] & $\mathrm{Rh}\left(\mathrm{NO}_{3}\right)_{3}$ & $\mathbf{g}$ & $3.64 \times 10^{2}$ \\
\hline [B] & RuNO(NOH) & 8. & $1.49 \times 10^{2}$ \\
\hline [C] & $\mathrm{Pd}\left(\mathrm{NO}_{3}\right)_{2}$ & $\mathbf{g}$ & $3.48 \times 10^{2}$ \\
\hline [D] & $4 \mathrm{M} \mathrm{HNO}_{3}$ & $\mathbf{L}$ & 25 \\
\hline [E] & $10 \mathrm{M} \mathrm{NaOH}$ & L & 5 \\
\hline$[\mathrm{F}]$ & Wash Water & L & 25 \\
\hline
\end{tabular}

(a) Highly toxic or carcinogenic components are shaded. 
T3C-95-148

Page 15 of 19

\subsection{Preparation and Addition of Minerals}

This part of the procedure provides instructions to prepare a mineral slurry. Quantities of the components can be found in Table 6.

A. Place [A] g of $\mathrm{Al}_{2} \mathrm{Si}_{2} \mathrm{O}_{5}(\mathrm{OH})_{4}$ in a furnace and heat to $650^{\circ} \mathrm{C}$. Hold at that temperature for 3 to 4 hours and cool.

B. To a fourth vessel (vessel 4), add [B] $\mathrm{L}$ deionized water. Add [C] $\mathrm{g}$ of $\mathrm{NaNO}_{3}$ and $[\mathrm{D}] \mathrm{g}$ of $\mathrm{NaOH}$ will continuously stirring.

C. Add $1.03 \times 10^{4} \mathrm{~g}$ of the calcined $\mathrm{Al}_{2} \mathrm{Si}_{2} \mathrm{O}_{5}(\mathrm{OH})_{4}$ while continuously stirring. Digest at $80^{\circ} \mathrm{C}$ for 5 hours with slow stirring.

D. Agitate the vessel contents and collect a representative sample for analysis. Analyze the sample (slurry analysis 5) and verify that cancrinite $\left\{\mathrm{Na}_{8} \mathrm{Al}_{6} \mathrm{O}_{24}\left(\mathrm{NO}_{3}\right)_{2} \cdot 4 \mathrm{H}_{2} \mathrm{O}\right\}$ was made. Document the composition of the product slurry.

E. Add approximately [E] L of water. Add components [F] through [H] given in Table 6 in the order and amount shown. This slurry should be prepared in a hood due to the carcinogenic nature of $\mathrm{SiO}_{2}$ with respiratory protection provided for personnel protection. Any insoluble components should be ground to a maximum diameter of $0.1 \mathrm{~mm}$ prior to being introduced to the tanks.

F. Transfer the slurry to the blend in vessel 1 as shown in Figure 1 .

Table 6: Mineral Phase Components ${ }^{(*)}$

\begin{tabular}{|c|c|c|c|}
\hline Item & Compound & Unit & Amount \\
\hline [A] & $\mathrm{Al}_{2} \mathrm{Si}_{2} \mathrm{O}_{5}(\mathrm{OH})_{4}$ & $\mathbf{g}$ & $1.20 \times 10$ \\
\hline [B] & Dilution Water & L & $4.00 \times 10$ \\
\hline$[C]$ & $\mathrm{NaNO}_{3}$ & $\mathbf{g}$ & $1.36 \times 10$ \\
\hline [D] & $\mathrm{NaOH}$ & $\mathbf{g}$ & $6.40 \times 10^{\circ}$ \\
\hline [E] & Dilution Water & $\mathbf{L}$ & 250 \\
\hline [F] & $\mathrm{AlOOH}$ & $\mathbf{g}$ & $1.43 \times 10^{-}$ \\
\hline [G] & Sio, & 8. & $3.09 \times 10$ \\
\hline [H] & $\mathrm{Na}_{2} \mathrm{SiO}_{3}$ & $\mathbf{g}$ & $9.40 \times 10^{3}$ \\
\hline
\end{tabular}

(a) Highly toxic or carcinogenic components are shaded. 


\subsection{Preparation and Addition of Sodium Nickel Ferrocyanide(}

This part of the procedure provides instructions to prepare $\mathrm{Na}_{2} \mathrm{NiFe}(\mathrm{CN})_{6}$ (Scheele et al. 1992). Quantities of the components can be found in Table 7.

A. To a fifth vessel (vessel 5), add [A] $\mathrm{L}$ of $4 \mathrm{M} \mathrm{NaNO}_{3}$ solution. Add [B] g of $\mathrm{Na}$. Fe(CN) while stirring continuously.

B. In a separate vessel, dissolve $[\mathrm{C}] \mathrm{g}$ of $\mathrm{Ni}\left(\mathrm{NO}_{3}\right)_{2}$ in deionized water. Stirring constantly, slowly add the dissolve $\mathrm{Ni}\left(\mathrm{NO}_{3}\right)_{2}$ to vessel 5 .

C. Add approximately [D] $\mathrm{L}$ of $10 \mathrm{M} \mathrm{NaOH}$ solution slowly to the solution in vessel 5 until the $\mathrm{pH}$ is in the range of 9 to 10 and stable (a variation of not more than $\pm 0.2 \mathrm{pH}$ units over 10 minutes).

D. After a pH between 9 and 10 is reached, continue to agitate the slurry for 1 hour at $70^{\circ} \mathrm{C}$. If the $\mathrm{pH}$ has dropped below 9 after the $1 \mathrm{hr}$ mixing period, add additional $\mathrm{NaOH}$ to return the $\mathrm{pH}$ to between 9 and 10. Turn heat off, and continue to stir for 12 hours or more.

E. Perform the wash/solids separation sequence (using a centrifuge and leaving a final volume such that the weight percent solids of the slurry is less than $20 \mathrm{wt} \%$ ) to lower the amount of soluble nitrate to less than $5 \mathrm{~g}$ for every liter of the final total volume (i.e. $1000 \mathrm{~L}$ ). The wash solution is to be deionized water. It is estimated based on past preparations, that 2 to 3 equivalent volumes of water, a total of $[E] L$, will be needed to reduce the nitrate concentration below the maximum allowable limit.

F. Agitate the vessel contents and collect a representative sample for analysis. Analyze the sample (slurry analysis 6 ) by drying in a vacuum oven at $60^{\circ} \mathrm{C}$ overnight and performing $\mathrm{XRD}$ analysis to verify that sodium nickel ferrocyanide was produced.

G. Transfer the washed slurry to the blend in vessel 1 as shown in Figure 1.

Table 7: Sodium Nickel Ferrocyanide Slurry Components ${ }^{(b)}$

\begin{tabular}{|c|l|c|c|}
\hline Item & Compound & Unit & Amount \\
\hline$[A]$ & $4 \mathrm{M} \mathrm{NaNO}_{3}$ & L & 15 \\
\hline$[B]$ & $\mathrm{Na} / \mathrm{Fe}\left(\mathrm{CN}_{6}\right.$ & $\mathrm{g}$ & $5.47 \times 10^{3}$ \\
\hline$[\mathrm{C}]$ & $\mathrm{Ni}\left(\mathrm{NO}_{3}\right)_{2}$ & $\mathrm{~g}$ & $3.29 \times 10^{3}$ \\
\hline$[\mathrm{D}]$ & $10 \mathrm{M} \mathrm{NaOH}$ & L & 8 \\
\hline$[\mathrm{E}]$ & Wash Water & L & 50 \\
\hline
\end{tabular}

(a) This procedure produces a form of cyanide equivalent to the form of cyanide in the tanks (verified by XRD analysis). Currently, PNL is verifying that the $\mathrm{CN}$ source is sodium nickel ferrocyanide. If any changes to this procedure are needed, a revision will be issued.

(b) Highly toxic or carcinogenic components are shaded. 


\subsection{Final Blend Adjustment}

This part of the procedure provides instructions to make the final concentration adjustments and lists the final requirements of the blend.

A. Agitate the vessel and collect a representative slurry sample of the final blend. Analyze the sample (slurry analysis 7) to determine the amount of the components. Major oxides, excluding sodium, should be within $\pm 10 \%$ of the values listed in Table 2. All other components must be with $\pm 15 \%$ of the values specified in Tables 3 through 8 . The weight percent solids should be between $15 \%$ and $20 \%$.

B. Adjust the nitrate, nitrite, and sodium concentrations using the values specified in Table 8. Nitrite should not be added until just before use because the nitrite degrades in the slurry. Sodium as $\mathrm{NaOH}$ should be added last since sodium will be also added in with the nitrate and nitrite.

C. The chemical composition and the physical properties of the slurry will constitute part of the acceptance documentation. The specifications required for acceptance are outlined in Section 3.0.

Table 8: Final Nitrate, Nitrite, and Sodium Ion Concentrations ${ }^{(\omega)}$

\begin{tabular}{|c|l|l|l|}
\hline Item & Ion & Source & $\begin{array}{l}\text { Target } \\
\text { Concentration } \\
(\mathrm{g} \mathrm{ion} / \mathrm{L})\end{array}$ \\
\hline$[\mathrm{A}]$ & $\mathrm{NO}_{3}^{\circ}$ & $\mathrm{NaNO}_{3}$ & $3.29 \times 10^{1}$ \\
\hline$[\mathrm{B}]$ & $\mathrm{NO}_{2}^{\circ}$ & $\mathrm{NaNO}$ & $1.74 \times 10^{\circ}$ \\
\hline$[\mathrm{C}]$ & $\mathrm{Na}^{+}$ & $\mathrm{NaOH}$ & $2.51 \times 10^{1}$ \\
\hline
\end{tabular}

(a) Highly toxic or carcinogenic components are shaded. 


\subsection{REQUIREMENTS AND SPECIFICATIONS}

1. The values of the following physical properties must be reported with the documentation:

$\begin{array}{ll}- & \text { weight percent solids } \\ - & \text { pH } \\ - & \text { gWOR } \\ \text { density }\end{array}$

2. Meeting the following specifications for the chemical composition is required. Certification must be included with the documentation:

Weight Percent Solids

Major Oxides (excluding Na):

Other Oxides

Anions (excluding $\mathrm{NO}_{2}^{-}$) and Total Organic Carbon

Sodium (before final adjustment)

Nitrite (before final adjustment)

Nitrate (before final adjustment)
15 to $20 \%$

$\pm 10 \%$ of values in Table 2

$\pm 15 \%$ of values in Tables $3,4,5,6$, and 7

$\pm 15 \%$ of values in Tables 3 and 4

$<0.4 \mathrm{~g} / \mathrm{L}$

$<1.7 \mathrm{~g} / \mathrm{L}$

$<32.9 \mathrm{~g} / \mathrm{L}$

3. Feed-stock chemicals are to be technical grade quality. Certification by the vendor of such (i.e. copies of supplier certification, etc) is required and copies must be included with the shipping documentation.

4. With the approval of a PNL technical representative, solutions of the nitrate chemicals or species having different waters of hydration can be used as starting material in place of the materials identified in the tables as long as the metal valence state remains the same. 
T3C-95-148

Page 19 of 19

\subsection{REFERENCES}

Agnew, S.F. 1994. Hanford Defined Wastes: Chemical and Radionuclide Composition. LAUR-942657, Los Alamos National Laboratory, Los Alamos, New Mexico.

Burger, L. L., D. A. Reynolds, W. W. Schulz, and D. M. Strachan. 1991. A Summary of Available Information on Ferrocyanide Tank Wastes. PNL-7822/AD-940, Pacific Northwest Laboratory, Richland, Washington.

Scheele, R.D., L.L. Burger, J.M. Tingey, R.T. Hallen and M.A. Lilga. 1992. Chemical Reactivity of Potential Ferrocyanide Precipitates in Hanford Tanks with Nitrates and Nitrites. WM 1992 Conference Proceedings, Tuscon, Arizona. 